\title{
Pushed out the Door, Back in through the Window: The Role of the ILO in EU and US Trade Agreements in Facilitating the Decent Work Agenda
}

\author{
Rafael Peels, International Labour Organisation \\ Marialaura Fino, International Labour Organisation ${ }^{1}$
}

\begin{abstract}
Although the debate on the inclusion of labour provisions in trade agreements seemed to be closed after the multilateral trade negotiations in the late 1990s, it is revived in the current negotiation of the EU-US Transatlantic Trade and Investment Agreement (TTIP). TTIP negotiations are of particular importance in this regard as the agreement is believed to set the norm for future negotiations. This paper examines the evolution of labour provisions in the EU and US trade agreements in the past two decades. It finds that: First, labour provisions are increasingly included in trade agreements of the US and the EU. Second, ILO instruments are the main reference here, and they often include an explicit reference to the decent work agenda. Third, reference to the role of the ILO in the implementation of labour commitments is less explicit, but leaves the door open for involvement in various ways, mainly through technical cooperation activities, monitoring or via a consultative role in dispute settlement mechanisms. The analysis leads to the conclusion that whereas the trade-labour linkage and the role of the ILO in trade may have been pushed out of the multilateral trade system, the discussion revived in the framework of pluri-lateral trade negotiations.
\end{abstract}

\section{KEYWORDS}

International Labour Organization, decent work agenda, international labour standards, trade agreements, United States, European Union.

\section{Introduction}

The multilateral trade negotiations in the late 1990s seemed to have closed the debate on the trade and labour linkage. However, the discussions on the inclusion of labour provisions in trade agreements (TAs) are revived in the current negotiations of the Transatlantic Trade and Investment Agreement (TTIP) between the European Union (EU) and the United States (US). The TTIP is believed to set a model for future TAs, since the EU and the US are among the main economic and geo-political players in the world economy.

The outcome of the multilateral trade negotiations in the 1990s conducted within the framework of the General Agreement on Tariffs and Trade (GAT'T) and the World Trade Organization (WTO) has been clear on the exclusion of social clauses from the multilateral trade system. ${ }^{2}$ The adoption of this position brought about significant consequences at the institutional level. Indeed, the 1996 Singapore Ministerial Declaration emphasises that the ILO (and not the W'TO) is the competent body to deal with international labour rights in the context of international 
trade (Leary, 1996; Orbie and Tortell, 2009). This has been an important debate for the International Labour Organisation (ILO) as it raised questions on the identification and nature of core labour standards (as later determined in the 1998 Declaration on Fundamental Principles and Rights at Work, hereinafter ILO 1998 Declaration) and the role of the ILO on the issue vis-à-vis the other big league players in the globalisation process (Hughes and Haworth, 2011).

The paper takes stock of the evolution of the issue and the implications for the ILO since then. In particular the focus is on the evolution of labour provisions in the EU and US trade agreements in the past two decades, that is, since 1994 when the North American Agreement on Labour Cooperation (NAALC) - the first TA that included labour provisions - entered into force. ${ }^{3}$ On the other side of the Atlantic, the first European trade agreement that included a labour provision was concluded by the European Community (EC) and the Republic of South Africa; the Trade, Development and Cooperation Agreement was signed in 1999 and entered into force in 2004. In this paper the term 'labour provisions' is defined as comprising (i) any labour standard which establishes minimum working conditions, terms of employment or worker rights, (ii) any norm on the protection provided to workers under national labour law and its enforcement, as well as (iii) any framework for cooperation in and/or monitoring of these issues (IILS, 2009, 2013). The ILO 1998 Declaration is the most common reference in these provisions, while the decent work agenda that builds on the ILO 1998 Declaration and on the Philadelphia Declaration of 1944 is also increasingly referred to. Indeed, all the EU's trade agreements since the agreement with Cameroon, signed in 2009 and entered into force in 2014, refer to the decent work agenda, while the fundamental elements of the labour provisions included in US trade agreements reflect the scope and principles of the decent work agenda.

In order to assess the actual and potential role of the ILO in EU and US trade agreements, the first section of this paper examines the rationale for including labour provisions in trade agreements. Next, the discussion on the trade and labour linkage is situated in its historic context. The third section focuses on its implications for the ILO and serves as an introduction to the fourth section in which the actual assessment of US and EU trade agreements is conducted. The paper concludes by opening up the debate towards the potential role of the ILO.

\section{Rationale for including Labour Provisions in Trade Agreements}

Two main stances can be distinguished in the broader trade and labour debate: a neo-liberal and a neo-institutionalism approach. The former tends to oppose the idea of labour provisions based on the self-regulatory capacity of markets. Improved labour standards might best be gauged in terms of market outcomes: increased demand for labour will lead to bidding up of wages, improved conditions of employment and prosperity for workers (Tsogas, 1999; Elliott, 2011). In this regard, labour regulations are essentially seen as distortionary measures that impede the efficient functioning of markets, leading to inferior outcomes in terms of growth, employment and income distribution (Lee, 1997; Haworth and Hughes, 1997). Proponents of a labour clause question the ability of markets to self-regulate. According to neo-institutionalists, an institutional framework, including labour standards, should contribute to channelling economic benefits into widespread social benefits, for instance as emphasised in the decent work agenda (Orbie, Gistelinck and Kerremans, 2009). Both positions come back when arguing for or against the inclusion of labour provisions in international trade agreements. Three main arguments can be distinguished: (i) the unfair competition argument; (ii) the race-to-the-bottom argument; and (iii) the moral and legitimacy argument (Trebilcock, 2003; Orbie et al., 2009).

The first argument goes in two directions and is interpreted differently from developed and developing country perspectives. Developed countries may argue that the non-compliance with 
international labour standards (ILS) creates unfair competition with those countries that do respect ILS. This concern has only been strengthened by a growing popular anxiety in developed countries of trade liberalisation's implications for jobs and wages in developed countries (Lee, 1997). The inclusion of a labour provision in trade agreements then should ensure a level playing field, where everyone that engages in international trade plays by the same set of rules (Doumbia-Henry and Gravel, 2006). The other way around, developing countries have been opposing labour provisions in trade instruments, based on fear of protectionist misuse by developed countries, as such jeopardising their comparative advantage in international trade. ${ }^{4}$

Along the lines of the previous argument, the trade-labour linkage is argued to counteract the threat of a race-to-the-bottom, whereby international competition to attract trade and investment may trigger countries to lower labour standards in order to regain a cost-based competitive advantage vis-à-vis those countries with lower labour standards. ${ }^{5}$ Other authors stress the positive impact of trade liberalisation, where economic growth and demand for labour may stimulate improvements in labour standards and result in a race-to-the-top (Haworth and Hughes, 1997).

The third argument is the moral and legitimacy argument. The core labour standards as referred to in the ILO 1998 Declaration are fundamental human rights, and non-compliance with these is normatively unacceptable and should be addressed through every possible means (including by using international trade as leverage). Furthermore, the inclusion of labour provisions in international trade agreements may contribute to preserving the legitimacy of the international trade system and as such prevent a popular and protectionist backlash against globalisation at large (Orbie et al., 2009).

\section{Situating the Trade and Labour Linkage in its Historic Context}

The debate on the linkage between trade and labour is not new. The setting of a minimum set of global rules to ensure the parallelism between the social and economic dimension of globalisation has been a leitmotif of the ILO since its establishment in 1919, which has been reaffirmed in the Philadelphia Declaration (1944), the ILO 1998 Declaration, the World Commission on the Social Dimension of Globalization (2004) and the Declaration on Social Justice for a Fair Globalization (2008, hereinafter ILO 2008 Declaration), which institutionalises the Decent Work concept developed by the ILO since 1999. ${ }^{6}$

The problem of social dumping - the increased competitiveness owing to low labour standards - was considered as early as the moment of defining the Constitution of the ILO (1919), stating that the failure of any nation to adopt humane conditions of labour is an obstacle in the way of other nations which desire to improve the conditions in their own countries. This was reaffirmed at the World Economic Conference convened by the League of Nations in 1927 (Charnovitz, 1987). ${ }^{7}$

The inclusion of labour provisions in international trade agreements was taken up in the Havana Charter (1948) with the intention to establish an International Trade Organization (ITO). The Charter provided for an institutional linkage between trade and core labour standards. It provided for cooperation with the ILO and foresaw that complaints about unfair labour conditions could be brought before the ITO's dispute settlement procedures (Orbie et al., 2009). The Charter, however, never entered into force. Instead the GATT entered into force in 1948, followed by the establishment of the WTO in 1994. Neither included provisions on the protection of labour rights in their regulations. ${ }^{8}$

The issue, however, has never been far from the trade agenda. Since the end of the Uruguay round (1994), the debate on the inclusion of a social clause in the GATT became increasingly politicised, culminating in the WTO Singapore Conference in 1996. Attempts to put this on the 
agenda at the WTO Millennium Round failed with the collapse of the 1999 WTO Seattle Ministerial Conference (Barry and Reddy, 2008).

The linking of trade and labour standards within the WTO was urged most strongly by the US, France and some other developed countries, such as Belgium, the Netherlands and Denmark, and opposed by a substantial number of newly industrialised economies in Asia, Latin America and developing countries, such as India, Egypt, Malaysia and Pakistan, but also Germany and the UK (Leary, 1996; Orbie et al., 2009). The US has been a driving force for the inclusion of a labour clause on the GATT/WTO agenda. In April 1987 the House of Representatives set the US negotiation objectives for the Uruguay round, and stated that one of them was 'to adopt, as a principle of GATT, that the denial of worker rights should not be a means for a country or its industries to gain competitive advantage in international trade.' The US even threatened to refuse to sign the WTO Singapore Declaration if it did not refer to labour standards (Leary, 1996).

In the same period, the European Parliament endorsed the concept of a GATT social clause (Charnovitz, 1987). The EU and its member states always insisted on dialogue, economic incentives or technical cooperation, rather than a sanctioning approach (Orbie and Tortell, 2009). Indeed, substantial disagreements within the EU existed on the social clause. ${ }^{10}$ While France, Belgium and the EP were the most enthusiastic supporters, Germany and the UK were openly opposed (Leary, 1996; Orbie and Tortell, 2009). ${ }^{11}$

\section{Implications for the ILO}

As a result, labour would not be part of the multilateral trade system, and accordingly nor would be the ILO in the follow-up of the international trade and labour debate. Several countries initially tried to keep the door open for debating labour issues in the WTO, for instance by proposing the establishment of a working group or a permanent W'TO-ILO forum; however, the matter gradually disappeared from the agenda. Also within the ILO, opinions on the labour clause were divided. On the one hand the employers' group has been generally opposed, while on the other hand the International Confederation of Free Trade Unions (ICFTU) had been in favour of the inclusion with significant divergence inside of the organisation (e.g. the Indian national Trade Union Congress has consistently opposed the idea). ${ }^{12}$ Also the government group was divided along the North-South divide, but also between important Northern countries (Haworth and Hughes, 1997). Furthermore, the sanction-based W'TO model of the social clause was expected to divide the organisation for not having a traditional ILO approach to labour standards, based on dialogue and moral persuasion, backed by technical cooperation (Haworth and Hughes, 1997; Hughes and Wilkinson, 1998).

The importance of the social clause debate for the ILO under GATT/WTO cannot be underestimated. It not only raised questions about the identification and nature of core labour standards, but also triggered debate on the nature of the ILO's instruments and supervisory mechanisms, and its role vis-à-vis the other big league players in the overall trade and labour debate (Standing, 2008; Hughes and Haworth, 2011). At the 81 ${ }^{\text {st }}$ session of the International Labour Conference (ILC) in 1994, the ILO Director-General argued in his report that 'the ILO should rely on cooperation rather than coercion in its effort to promote social progress'. The Director-General questioned whether it was 'possible to reconcile this voluntary approach, which is the basis for the universal confidence the ILO enjoys with its vocation to strengthen the effectiveness of its standardsetting activities for the regulation of international trade?' (ILO, 1994a).

The same year, the ILO established a working group on the social dimension of the liberalisation of international trade. The working group identified a limited list of core ILO Conventions that would result in the ILO 1998 Declaration (Maupain, 2012). This also raised 
questions about the implications of the reference to international labour standards (ILS) in an extraILO forum, such as the WTO. Bringing ILS under the WTO would not only have passed the guardianship of labour standards to another international institution. In addition, in contrast to the ILO's main weapons - dialogue, persuasion and technical cooperation - the WTO would have a different compliance mechanism, based on sanctions (Haworth and Hughes, 1997; Hughes and Wilkinson, 1998).

\section{References to the ILO standards system in EU and US Trade Agreements}

Following a brief discussion of the broad trade-and-labour-linkage debate, including the implications for the ILO, the analysis now narrows its focus to the EU and US case studies. The paper examines the reference to ILO instruments and the potential role of the ILO in the follow-up of labour commitments by examining all EU and US trade agreements that include a labour provision (starting with the NAALC in 1994). A comparative analysis is conducted along the lines of (a) the legal content of the provisions, and (b) the implementation mechanisms in place, which mainly consist of dispute resolution mechanisms, the possibility of carrying out cooperative activities, and monitoring.

\section{Legal Content}

The first trade agreement signed by the US that addressed labour issues was the North American Agreement on Labour Cooperation (NAALC), a side agreement of the North American Free Trade Agreement (NAFTA). Since then, every trade agreement concluded by the US has included labour provisions in the main agreement. However, the legal content of the provisions changed with time. Besides NAALC, only the agreements signed since 2006 contained an explicit reference to the rights as stated in the ILO 1998 Declaration, while those signed between 1994 and 2006 did not refer to the principle of non-discrimination.

In more detail, NAALC refers to eleven labour standards, including the four core ILO standards as later defined in the 1998 Declaration, although without making explicit reference to the respective ILO instruments. ${ }^{13}$ The first series of trade agreements concluded after NAFTA (all signed before February 2006) included those with Jordan, Chile, Singapore, Australia, Morocco, Bahrain, CAFTA-DR and Oman. They all referenced the 1998 ILO Declaration in the core text of the agreement, but limited the definition of 'internationally recognized labour rights' to three of the four standards in the 1998 ILO Declaration - that is, excluding the principle of non-discrimination. Furthermore, all these trade agreements, excluding Bahrain and Jordan, also contained a specific reference to ILO Convention 182 on the worst forms of child labour. The second series of trade agreements, concluded with South Korea, Panama and Colombia (signed after March 2006), added to the first series by including the reference to the fourth ILO core principle of non-discrimination into the text of the agreements. Furthermore, all the trade agreements concluded by the US refer to the minimum working conditions (minimum employment conditions in NAALC) - that is, acceptable conditions of work with respect to minimum wages, hours of work, occupational safety and health, recognised as principles of the ILO decent work agenda (ILO, 2008: article I(a)ii).

The NAACL required the parties to enact labour laws that reflect high labour standards and to 'effectively enforce' their domestic labour laws with regard to the 11 labour principles listed. Although the requirement of effective enforcement of domestic labour law remained, the incorporation of international labour standards into domestic labour law was only demanded in the most recent agreements. Indeed, the first series of trade agreements after NAACL called for the parties to 'strive to ensure' that international labour standards were incorporated into the domestic law and 'strive to ensure' they do not derogate from domestic law. The second set of trade 
agreements signed after March 2006 eliminated the hortatory language creating positive obligations for the parties to incorporate the rights listed in the ILO 1998 Declaration into domestic law and not to derogate from domestic labour legislation. The most recent trade agreements also narrowed the enforcement obligation by stating that parties shall not fail to effectively enforce labour laws 'through a sustained or recurring course of action or inaction, in a manner affecting trade'. Therefore, a party would not be liable for a breach of the trade agreement for a single incident of non-enforcement nor for failure to enforce labour laws in areas that do not affect trade.

On the other side of the Atlantic, the first European trade agreement that included a labour provision was concluded by the European Community (EC) and its Member States with the Republic of South Africa in 2004. EU trade agreements concluded with South Africa and Chile (in 2005) include explicit reference to ILO standards derived from the ILO Fundamental Conventions in the main articles of the agreement. The vast majority of the EU's trade agreements include reference to the ILO 1998 Declaration and the 2006 Ministerial Declaration of the UN Economic and Social Council on Full Employment and Decent work. ${ }^{14}$ Indeed, as stressed before, decent work has been in the EU trade agenda since 2009. Furthermore, the ILO Fundamental Conventions have been referred in agreements with South Korea, Ukraine, Colombia and Peru.

Other EU agreements place stronger emphasis on dialogue and cooperation on specific labour matters, for example on working conditions in migrant communities and anti-discrimination in the association agreements with Morocco and Jordan. In the Free Trade Agreement (FTA) with Iraq, however, emphasis is placed on labour legislation, decent work, Occupational Safety and Health $(\mathrm{OSH})$ and gender equality. Other agreements require the parties not to lower their labour standards and to effectively implement their domestic labour law. CARIFORUM and the trade agreements with Ukraine and Georgia also require the parties to ensure their domestic legislation calls for high levels of labour protection while not requiring effective enforcement of their labour law. Going a step further, the recent agreement with Georgia uniquely requires the parties to adopt laws consistent with international labour standards (and not only calling for high levels of labour protection), while striving to provide for high levels of labour enforcement. ${ }^{15}$

In conclusion, in terms of normative content EU and US approaches converge in the reference to the ILO 1998 Declaration, and substantially in the reference to the scope and principles of the ILO decent work agenda as established in the ILO 2008 Declaration. However, while the EU progressively points towards the ratification of specific ILO conventions, as is the case in the recent agreements with Korea, Colombia and Peru and Central America, the US focus is on the effective implementation of national legislation that has to incorporate labour rights as listed in the 1998 Declaration.

Along the same line, reference to specific ILO conventions rather than to the ILO 1998 Declaration has different legal implications. When the ILO 1998 Declaration is referred to, the legal content of the referral is rather broad as the Declaration contains an enunciation of principles and rights. Therefore, absent the previous ratification by the State, ILO members only commit to the principle concerning these rights, but not to the concrete rights set out in the relevant Conventions. Furthermore, as the 1998 Declaration is not subject to monitoring by the regular ILO's supervisory mechanisms, no specific guidance by the ILO on the Declaration is available. ${ }^{16}$ This lack of clarity may affect the coherent implementation of labour provisions in case of a dispute arising from trade agreements (Agustí-Panareda, Ebert and Leclerq, 2014).

However, the referral to ILO instruments (and the implicit difference among the instruments referred to) is not the only relevant issue for the involvement of the Organization. Additional important considerations have to be made with regard to the implementation of these commitments. Differences exist in the conflict resolution mechanisms, where the ILO could potentially play a role and where EU and US approaches remarkably diverge. Furthermore, technical cooperation and monitoring by third parties are important mechanisms to follow up on the implementation of the 
commitments taken on labour matters. These different mechanisms will be discussed in the following sections.

\section{Conflict Resolution}

The NAALC called for a three-tiered system for addressing violations of its labour provisions based upon the international labour standards violated. Under NAACL, public complaints regarding labour violations may be submitted to the National Administrative Office (NAO) of each party and arbitration, which may lead to monetary assessments or a suspension of benefits, can only be initiated for complaints related to a limited number of issues (occupational safety and health, child labour and minimum wage). ${ }^{17}$ This means, for instance, that the non-compliance with the right of freedom of association and collective bargaining cannot be subject to the mechanism for dispute settlement. The US trade agreements after NAACL have been divided into two groups. One group provides for dispute settlement only when a country fails to comply with the obligation to effectively enforce its labour laws, ${ }^{18}$ while the other group permits dispute settlement for all provisions in the labour chapter, for instance for the failure to promote public awareness of labour laws. ${ }^{19}$ In all cases dispute settlement may result in a monetary assessment or suspension of benefits. Additionally, the trade agreements usually call for parties to consult with one another before invoking the dispute settlement mechanisms, and call for a committee or council to review the dispute prior to dispute settlement if the consultations fail. For the trade agreements that only permit dispute settlement for allegations of failing to enforce domestic labour law, consultations and the committee or council review are the only options for conflict resolution resulting in a less stringent obligation given the lack of sanctions. The official involvement of the ILO is not foreseen in any of the mechanisms established in the different types of agreements.

Dispute resolution for violation of the labour provisions takes different forms in EU trade agreements. Most recent trade agreements include mechanisms for conflict resolution, via governmental consultations or a panel of experts. However, differently from the US trade agreements, the mechanisms do not foresee the resort to state-state arbitration with the possibility of sanctions. Again differently from the US, in the most recent agreements with Korea, Colombia, Peru and Central America the provisions on governmental consultations establish that in resolving the dispute 'ILO initiatives' are to be taken into consideration.

\section{Cooperative Activities}

In general, the cooperative activities included in US trade agreements have not changed much over the years: trade agreements usually list a set of priority areas for cooperation. For example, in NAALC, there are 15 priority areas listed, including occupational health and safety (OHS), child labour and labour statistics. ${ }^{20}$ The agreement also stresses the opportunity of establishing cooperative activities with the ILO in order to draw on the expertise of the Organization. ${ }^{21}$ Almost every agreement concluded after NAALC included cooperation on the implementation of fundamental rights and working conditions, in some cases explicitly referring to the ILO 1998 Declaration (e.g. the US-Chile agreement). ${ }^{22}$ Elimination of the worst forms of child labour is also a common area of cooperation, sometimes in connection with the explicit reference to ILO Convention $182 .{ }^{23}$ The implementation of the activities has been carried out in the TAs by using seminars, joint research projects and technical assistance. In some cases, the direct involvement of the ILO is explicitly mentioned, usually in agreements parallel to the trade agreement. For example, the Joint Declaration of Trade and Labor Ministers of Central America and the Dominican Republic addresses the labour dimension of the CAFTA-DR and calls upon the support of the ILO to enhance labour law compliance and institutional capacity in the region. Additionally, the USColombia Labor Action Plan states that 'the Colombian government will seek the cooperation, 
advice, and technical assistance of the ILO to help in the implementation of the measures outlined in this document related to labor rights'.

Unlike the US trade agreements, the areas of cooperation vary greatly from agreement to agreement concluded by the EU, reflecting the intent to tailor cooperative activities to the specific needs of the parties to the agreement. Several EU trade agreements reference the ILO decent work agenda in their cooperation section, and suggest that parties engage in activities related to the Agenda. ${ }^{24}$ In particular, the agreements promote the cooperation in trade-related aspects of the ILO decent work agenda, most naturally in the international forum responsible for labour aspects of trade and sustainable development, that is, the ILO. Other agreements focus on specific areas where parties could cooperate. For example, in the trade agreement with Iraq, the parties agreed to cooperate in decent work, OHS and gender equality without, however, explicitly referring to the ILO. $^{25}$ The Jordan agreement only mentions cooperation on working conditions in migrant communities, and the trade agreement with Moldova encourages cooperation on eliminating child labour as it is quite prevalent and is seriously affected by the Worst Forms of Child Labour Convention (WFCL). ${ }^{26}$

\section{Monitoring Mechanisms}

Both the US and EU trade agreements provide institutional mechanisms to monitor compliance with labour provisions. Depending on the agreement, the Parties may commit to establish a Labor Affairs Council, a Contact Point, a Cooperation Council or a Committee on Trade and Sustainable Development.

NAALC provides for various joint bodies at the ministerial and administrative levels to follow up labour issues, and for a stand-alone body, the Secretariat of the Commission for Labor Cooperation, with specific tasks and responsibilities. ${ }^{27}$ In successive agreements, these functions have been carried out by the Office for Trade and Labor Affairs (OTLA), an Office within the US Bureau of International Labor Affairs tasked with the overall implementation of trade-related labour policy and the coordination of international technical cooperation in support of the labour provisions in FTAs. ${ }^{28}$ In general terms, monitoring consists in regular reporting (available to the public) on the implementation of the labour chapter. Additionally, agreements foresee the possibility to seek advice from non-state actors, to establish a national advisory committee or consult an existing advisory body. ${ }^{29}$ Overall monitoring mechanisms may exist even though they may not be necessarily mentioned in the trade agreements. Reference to the possible role of the ILO in this regard is ambiguous. While in previous agreements no explicit reference was made to the possible role of the ILO in the monitoring of the TAs, in the most recent wave of agreements, explicit reference is made towards the possible consultation of international organisations, including the ILO, in the activities of the national contact points. ${ }^{30}$

Recent EU trade agreements provide for the establishment of a particular subcommittee to follow up on the implementations of the Trade and Sustainable Development Chapter in a more comprehensive way than previous agreements. In this regard, cooperation with and between the respective parliaments, economic and social committees, domestic advisory committees and civil society forums may be referred to. ${ }^{31}$ For example, the EU-CARIFORUM trade agreement includes one article on consultation and monitoring activities in decent work and sustainable development areas. $^{32}$ As for the US, reference to the ILO with regard to monitoring by the respective institutional arrangements is ambiguous. Although overall reference may be made to seek advice from the ILO on any labour-related matter or during government consultations, no explicit reference is made to its role in monitoring activities. 


\section{Conclusions on the Actual and Potential Role of the ILO}

The debate on the social clause in international trade agreements has been revived in the last decades, and even more so in the current negotiation process of the EU-US TTIP. By assessing the US and EU trade agreements concluded in the past two decades, this papers finds an increasing incidence of reference to ILO instruments to facilitate the linkage between international trade and decent work.

Although differences exist between the US and EU approaches, a convergence can be observed, in particular with regard to the adoption and effective implementation of domestic labour legislation which should be in compliance with the ILO's standards system as set up in the 1998 Declaration. In the case of the $\mathrm{EU}$, additional reference may be made to the effective implementation of specific ILO Conventions, and in some cases to the sustained effort towards ratification. Also other ILO instruments, such as the decent work agenda, is increasingly referred to as a basis for cooperative activities.

While the widespread reference to ILO instruments in both US and EU trade agreements is evident, reference to the role of the ILO in the implementation of their labour commitments is less explicit. Both US and EU stress the importance of cooperation activities in several labour-related areas, including to cooperate in international forums such as the ILO. In some cases, for example EU-CARIFORUM, the possibility to seek advice from the ILO on best practices, the use of effective policy tools or the implementation of labour standards is referred to. Various agreements do establish parallel cooperation agreements that make the consultation or involvement of the ILO more explicit, such as the US-Colombia Labor Action Plan and the Joint Declaration of Trade and Labor Ministers of CAFTA-DR.

In terms of overall monitoring, US and EU trade agreements provide for the establishment of institutional arrangements to follow-up on the compliance with labour commitments. The most explicit reference towards the role of the ILO is contained in the most recent US trade agreements, which mention the possibility of the National Contact Points to seek advice from the ILO.

Furthermore, government consultations in the dispute settlement mechanisms of the recent EU trade agreements with South Korea, Colombia/Peru and Central America may take into consideration ILO initiatives. On the other hand, no formal reference is made to a role for the ILO in dispute settlement mechanisms under US trade agreements.

In brief, reference to ILO standards and the potential involvement of the ILO in the agreements has become more common practice. However, this fact raises some questions with regard to the implications for the ILO. The assessment of the compliance with international labour standards in other forums outside of the ILO may hold a risk of inconsistent interpretation.

For example, since 1990 the ILO's regular supervisory system has examined on several occasions the issue of trade union rights in Guatemala. In response to the limited progress made, worker delegates to the $101^{\text {st }}$ Session of the International Labour Conference (2012) requested the establishment of a Commission of Inquiry against the government of Guatemala concerning the non-observance of Convention 87. Since then, the decision has been postponed, although different measures have been taken to address this request. ${ }^{33}$ Parallel to this process, a submission has been filed under CAFTA-DR against the government of Guatemala (2008) motivated by similar violations and based, to a certain extent, on some of the analysis carried on under the ILO's supervisory mechanisms. After various initiatives to seek compliance with the labour commitments, that is, the establishment of a US-Guatemala Enforcement Plan that brought limited results, the US administration has re-activated the arbitration procedure provided for in the agreement. Although the US administration relies to some extent on the comments of the ILO's supervisory bodies to support the claim that Guatemala has violated its labour commitments under CAFTA-DR, it is ultimately the Arbitration Panel constituted under CAFTA-DR rules that will interpret the 
application of certain ILO standards in Guatemala and formulate recommendations on how to address non-compliance.

As it is an increasing reality that international labour standards and specific mechanisms to monitor their compliance are included in a variety of international policy instruments, such as trade agreements, the case of Guatemala might be followed by additional ones in the future. Crossreference, that is the referral of international labour standards in the trade agreements, as well as the consideration of ILO activities in the decision-making process for the resolution of disputes related to trade and labour makes the different regimes not self-contained. From this perspective, the increasing references to ILO instruments in trade agreements, as well as the explicit mention of the possibility to request technical assistance from the ILO as linked with the agreements, opens the door for a more active ILO involvement. It is in the interest of the ILO, as per its constitutional mandate, that its international standards system is implemented consistently across agreements and around the world.

Indeed, the ILO's constitutional mandate - which includes the promotion of compliance with international labour standards, the provision of technical assistance and the fostering of legal certainty on the meaning and implications of international labour standards - provides a broad basis to assist states (on a voluntary basis and upon request) in giving effect to labour provisions in trade agreements. Furthermore, the ILO 2008 Declaration, explicitly equips the ILO to provide various forms of assistance to its members within the framework of bilateral and multilateral agreements to ensure compatibility with ILO obligations (Art. II, a, iv).

In this regard, Agustí-Panareda et al. (2014) suggest various possible ways for the involvement of the ILO, mainly through providing assistance with (i) the clarification of the scope, legal content and implications of the international labour standards referred to in the labour provisions; (ii) the assessment of compliance with ILO instruments; (iii) fact-finding missions on the labour situation in specific countries; (iv) mediation during labour disputes; or (v) addressing compliance issues through technical cooperation, monitoring or research activities.

On this subject, an additional institutional question consists in the identification of the appropriate body within the ILO, and its supervisory system and procedures - for example, tripartite and/or expert-based - to manage and coordinate requests and assistance to enable the effective implementation of the decent work agenda through social clauses in trade agreements. However, the answer to this question lies outside the scope of this paper. Instead this analysis is meant to contribute to the debate on the role of the ILO in EU and US trade agreements in view of the ongoing TTIP negotiations. Today, pluri-lateral engagements open the window for the 'trade and labour' discussion to be back in, after the door seemed to be shut two decades ago.

\section{NOTES}

1. We would like to thank Phoebe Moore, Conor Cradden and Elizabeth Echeverria for their helpful comments and contributions. Any views expressed or conclusions drawn represent the views of the authors and not of the ILO.

2. Multilateral trade negotiations in the 1990s refers to the Uruguay Round (1986-1994) and to the Singapore and Seattle Ministerial Conferences of 1996 and 1999 respectively.

3. The NAALC was signed between the US, Canada and Mexico.

4. See Haworth and Hughes (1997) for a debate on the protectionist argument of the social clause. 
5. See Bhagwati (1994), OECD (1996) and Tsogas (1999) for a discussion on whether core labour standards, understood as human rights, and broader socio-economic standards such as minimum working conditions, may affect competitiveness, thus putting the race-to-thebottom hypothesis into perspective.

6. The Decent Work concept was introduced in 1999 and institutionalised in the 2008 Declaration on Social Justice for a Fair Globalization.

7. See Charnovitz (1987) for a historic overview of the interplay between ILS and the world trading regime.

8. With the exception of GATT Article XX(e), which permits governments to ban trade in goods produced using prison labour.

9. H.R. 3, $100^{\text {th }}$ Congress, $1^{\text {st }}$ Session, section 111 (b) (10), 8 May 1987.

10. Conflicts over the EC's competence in the fields of trade and labour vis-à-vis its member states also contributed to the lack of this European consensus (Orbie et al., 2009).

11. Owing to a shift in the government in power in Germany, its position at the Seattle Conference was more favourable compared to the Singapore Conference (Orbie et al., 2009).

12. The ICFTU was dissolved in 2006 when it merged with the World Confederation of Labour (WCL) to form the International Trade Union Confederation (ITUC).

13. NAALC, Annex I, Labour Principles. 'Freedom of association and protection of the right to organize; the right to bargain collectively; the right to strike; prohibition of forced labor; labor protections for children and young persons; minimum employment standards, such as minimum wages and overtime pay, covering wage earners, including those not covered by collective agreements; elimination of employment discrimination on the basis of grounds such as race, religion, age, sex, or other grounds as determined by each Party's domestic laws; equal pay for men and women; prevention of occupational injuries and illnesses; compensation in cases of occupational injuries and illnesses; protection of migrant workers.'

14. TAs with South Africa, Chile, Cameroon, Jordan, Eastern and South Africa, Morocco and Iraq do not contain both of these references. The trade agreements with Colombia and Peru only refer to the UN Declaration but not to the 1998 ILO Declaration.

15. EU-Georgia Association Agreement, Article 228(1).

16. The Follow-up Mechanism of the 1998 Declaration is intended to assist the ILO complete technical cooperation activities to help countries implement fundamental principles and rights. The Follow-up Mechanism includes an annual review for countries who have not yet ratified conventions to provide information regarding their progress in ratifying fundamental ILO Conventions and a global report assessing the four categories of fundamental principles and rights at work emphasised in the 1998 ILO Declaration.

17. NAALC, Article 29(1).

18. Trade agreements with Morocco, Australia, Singapore, Chile, Bahrain, CAFTA-DR and Oman.

19. Trade agreements with Chile, Peru, South Korea, Colombia and Panama.

20. NAALC, Article 11. The focus areas may be listed in either the labour chapter or the annex to the labour chapter, a common feature in US trade agreements.

Global Labour Journal, 2015, 6(2), Page 199 
21. NAALC, Article 45.

22. The Jordan and the Australian agreements do not specifically list any areas of focus.

23. Cooperation of the WFCL is included in agreements with Morocco, CAFTA, Peru, South Korea, Colombia and Panama.

24. CARIFORUM TA, TAs with South Korea, Colombia and Peru, Moldova and Georgia.

25. EU-Iraq Partnership and Cooperation Agreement, Article 84(1).

26. Direct Request (CEACR) - adopted 2012, published 102nd ILC Session (2013), Worst Forms of Child Labour Convention, 1999 (No. 182) - Moldova, Republic of. [Online] Available at http://www.ilo.org/dyn/normlex/en/f?p=NORMLEXPUB:13100:0::NO:13100:P13100_CO MMENT_ID:3084805:NO [Accessed 17 April 2015].

27. Article 14 of NAALC.

28. The establishment and the functioning of the OTLA is contained in a Notice of the Department of Labor, Office of the Secretary, Bureau of International Labor Affairs; Notice of Reassignment of Functions of Office of Trade Agreement Implementation to Office of Trade and Labor Affairs; Notice of Procedural Guidelines in the Federal Register Notice, Vol. 71, No. 245, December 21, 2006, 76991 available at http://webapps.dol.gov/FederalRegister/PdfDisplay.aspx?DocId=12492 [Hereinafter US OTLA Procedural Guidelines].

29. E.g. article 15.1 and 15.3 of the US-Jordan TA; article 18.4.6 of the US-Chile TA.

30. Article 17.5.5.iv of the US-Peru or US-Colombia trade agreements.

31. The EU-Central America Association Agreement provides for the establishment of a Joint Consultative Committee (article 10). The EU-Republic of Korea, EU-Peru/Colombia and EU-Central America TAs provide for the possible consultation of existing, or establishment of, Domestic Advisory Committees. The TA between the EU and Central America provide for increased dialogue between parliaments through an Inter-Parliamentary Committee. However, this has been left out in the EU-Republic of Korea or EU-Colombia and Peru TAs.

32. Article 195 of the EU-CARIFORUM Trade Agreement.

33. The steps taken to address the request are: (i) the execution of a Memorandum of Understanding (MoU, March 2013) between the Chairperson of the Worker's group of the Governing Body of the ILO and the Government of Guatemala; (ii) the adoption of a roadmap (October 2013) adopted in consultation with national social partners to apply the MoU; (iii) the monitoring by ILO missions to follow up the implementation of the roadmap (last on September 2014); and (iv) follow-up of the progress by the Governing Body (last in March 2015) and the International Labour Conference (last in June 2014).

\section{REFERENCES}

Agustí-Panareda, J., Ebert, F. and Leclerq, D. (2014) Labour provisions in free trade agreements: Fostering their consistency with the ILO standards system, Background Paper. Geneva: ILO.

Barry, C. and Reddy, S.J. (2008). International trade and labor standards. A proposal for linkage. New York: Columbia University Press. 
Bhagwati, J. (1994) Free trade, 'fairness' and the new protectionism, Institute of Economic Affairs Occasional Paper, $\mathrm{N}^{\circ}$ 96. London: IEA.

Charnovitz, S. (1987) 'The influence of international labour standards on the world trading regime. A historical overview', International Labour Review, 126(5): 565-584.

Doumbia-Henry, C. and Gravel, E. (2006). 'Free trade agreements and labour rights: Recent developments', International Labour Review, 145(3): 185-206.

Elliott, K.A. (2011) 'Labor Rights', in Chauffour, J.-P. and Maur, J.-C. (eds.) Preferential trade agreement policies for development. A handbook. Washington DC: The World Bank.

Haworth, N. and Hughes, S. (1997) 'Trade and international labour standards: Issues and debates over a social clause', The Journal of Industrial Relations, 39(2): 179-195.

Hughes, S. and Wilkinson, R. (1998) 'International labour standards and world trade: No role for the World Trade Organization', New Political Economy, 3(3): 375-389.

Hughes, S. and Haworth, N. (2011) 'Global institutions. The International Labour Organisation (ILO). Coming in from the cold. Oxon: Routledge.

International Institute for Labour Studies (IILS) (2009) 'Rebalancing globalization: The role of labour provisions in existing international trade arrangements and development finance policies', World of Work report 2009: The global jobs crisis and beyond. Geneva: ILO.

International Institute for Labour Studies (IILS) (2013) Studies on growth with equity. Social dimensions of free trade agreements. Geneva: ILO.

International Labour Organization (ILO) (1919) Constitution. Geneva: ILO.

International Labour Organization (ILO) (1994a) Defending values, promoting change. Social justice in a global economy: An ILO agenda, Report of the Director-General (Part I), International Labour Conference $81^{\text {st }}$ Session 1994. Geneva: ILO.

International Labour Organization (ILO) (1998) Declaration on fundamental principles and rights at work. Geneva: ILO.

International Labour Organization (ILO) (2004) World Commission on the Social Dimention of Globalization. Geneva: ILO.

International Labour Organization (ILO) (2008) Declaration on social justice for a fair globalization. Geneva: ILO.

Leary, V.A. (1996) 'Workers' rights and international trade: The social clause (GAT'T, ILO, NATO, U.S. Laws)', in Bhagwati J.N. and Hudec R.E. (eds.) Fair trade and harmonization. Prerequisites for free trade?. Vol. 2: Legal Analysis. Cambridge: The MIT Press.

Lee, E. (1997) 'Globalization and labour standards: A review of issues', International Labour Review, 136(2): 173-189.

Maupain, F. (2012) L'OIT à l'épreuve de la mondialisation financière. Genève: IILS-ILO.

Organisation for Economic Cooperation and Development (OECD) (1996) Trade, employment and labour standards. A study of core workers' rights and international trade. Paris: OECD.

Orbie, J. and Tortell, L. (2009). 'The new GSP+ beneficiaries: Ticking the box or truly consistent with ILO findings?' European Foreign Affairs Review, 14(3)L 663-681. 
Orbie, J., Gistelinck, M. and Kerremans, B. (2009) 'The social dimension of EU trade policies,' in Orbie, J. and Tortell, L. (eds.) The European Union and the social dimension of globalisation. How the EU influences the world. Garnet Series: Europe in the World. Oxon: Routledge.

Standing, G. (2008) 'The ILO: An agency for globalization', Development and Change, 39(3): 355-384.

Trebilcock, M. J. (2003) International trade and international labour standards. Available online at http://www.yorku.ca/drache/talks/pdf/doha_trebilcock.pdf (Accessed 3 May 2015,

Tsogas, G. (1999) 'Labour standards in international trade agreements: An assessment of the arguments', The International Journal of Human Resource Management, 10(2): 351-375.

World Commission on the Social Dimension of Globalization (2004) A fair globalization: Creating Opportunities for All. Geneva: ILO.

\section{BIOGRAPHICAL NOTES}

RAFAEL PEELS, PhD, is Research Officer at the ILO. He can be reached at peels@ilo.org.

MARIALAURA FINO, M.Sc., LLM, is Research Officer at the ILO. She can be reached at fino@iloguest.org. 